\title{
Film Education Journal
}

Article

Sixteen years of 'Cinema in progress': Exploring Cinema en curs's holistic approaches to film education in conversation with Núria Aidelman and Laia Colell

\section{Jamie Chambers (ic)}

Lecturer in Film and Television, Edinburgh College of Art, University of Edinburgh, UK; jamie.chambers@ed.ac.uk Submission date: 30 March 2021; Acceptance date: 14 May 2021; Publication date: 23 November 2021

\section{How to cite}

Chambers, J. (2021) 'Sixteen years of "Cinema in progress": Exploring Cinema en curs's holistic approaches to film education in conversation with Núria Aidelman and Laia Colell'. Film Education Journal, 4 (2), 108-24. DOI: https://doi.org/10.14324/FEJ.04.2.02.

\section{Peer review}

This article has been peer-reviewed through the journal's standard double-blind peer review, where both the reviewers and authors are anonymised during review.

\section{Copyright}

2021, Jamie Chambers. This is an open-access article distributed under the terms of the Creative Commons Attribution Licence (CC BY) 4.0 https://creativecommons.org/licenses/by/4.0/, which permits unrestricted use, distribution and reproduction in any medium, provided the original author and source are credited • DOI: https://doi.org/10.14324/FEJ.04.2.02.

\section{Open access}

Film Education Journal is a peer-reviewed open-access journal.

\begin{abstract}
Established in Catalonia in 2005, Cinema en curs is now one of the most significant film education projects worldwide. This article places selections from interviews conducted in early 2021 with project founders and directors Núria Aidelman and Laia Colell within a critical context drawing upon international considerations of film education, including previous explorations of Cinema en curs. Discussion is separated into two distinct yet interconnecting sections: first upon the institutional and media-ecological contexts in which Cinema en curs takes place (and the complex considerations informing the project's shape and manner of delivery that arise from these contexts); and, second, upon the different cultural, aesthetic and political priorities that inform the project's approach to methodology and pedagogy.
\end{abstract}

Keywords Catalonia; Spain; film education; Cinema en curs; student film-making; place-based learning; Cinéma Cent Ans De Jeunesse 
The approximate English translation of 'Cinema en curs', the title of A Bao A Qu's long-running Catalan film education project, is 'Cinema in progress'. It would thus seem fitting that attempting to present a coherent picture of Cinema en curs at the time of writing is akin to taking a photograph of something in motion, already changing shape at the moment in which one attempts to attribute it a fixed form. Established in 2005 by the Catalan cultural organisation A Bao A Qu led by Núria Aidelman and Laia Colell, Cinema en curs is now delivered internationally in Galicia, Madrid, Euskadi, Andalusia, the Balearic Islands, Germany, Chile and Mexico, making it one of the furthest-reaching film education projects currently delivered in the world. As a student of influential French ciné-pedagogical theorist Alain Bergala (whose work is explored in the inaugural issue of the Film Education Journal (Burn, 2018; Chambers, 2018; Gibbs, 2018; Reid, 2018)), Aidelman became the first international collaborator to begin delivering the Bergala-led Cinéma Cent Ans De Jeunesse (CCAJ) project outside France in 2005 (Chambers, 2020: 138), not coincidentally the same year in which Cinema en curs was delivered for the first time in Catalonia. In certain key respects Cinema en curs can be seen to have grown directly out of CCAJ, albeit charting from the outset its own autonomous, yet parallel, path, whereby a small number of participants in Catalonia continue to engage with the formalised structure of CCAJ each year, while the wider majority of participants within Cinema en curs follow an individuated programme drawing certain strengths from core aspects of CCAJ's approach, while continuing to make its own considered modulations and refinements. For, while it continues to display a clear indebtedness to Bergala's philosophy of film education (Aidelman and Collel, 2012: 124) and aspects of CCAJ's core methodology, Cinema en curs has developed its own, highly particular identity (as is explored below), and indeed through Aidelman and Colell's ongoing participation in Cinéma Cent Ans - now itself exerts significant influence upon its parent project.

In 2012, Aidelman and Colell wrote that it 'is a further aim of Cinema en curs: to become a thought laboratory, generating proposals and methodologies for film dissemination that can be applicable to diverse contexts' (see English translation - Aidelman and Colell, 2021: 60). This notion of a 'thought laboratory' is perhaps one of the key reasons why Cinema en curs is so hard to tie down, given the project's prioritisation of a dialogical, discursive approach, continually reshaping itself in constant conversation with the young people, teachers and film-makers who participate each year. As Aidelman described in a conversation via Zoom in early 2021:

... everything in Cinema en curs is very collaborative - the ideas, the workshops, and so forth. We work and communicate very closely throughout the project with the teachers and filmmakers who are delivering the activities and are very close to the day-to-day experiences: we know what happened, what worked and what didn't, and it really allows us to reflect on what is working [and react.] So we'll have ideas that are emerging from a workshop today and we can tell the film-maker who is going to another workshop tomorrow to try out the ideas. It's a live experience. It's not a project where we give out the tasks and then we don't see anyone until the end of the year. We talk every day. It's evolving and thinking day to day with meetings among the team.

In this respect, Cinema en curs can be seen to share something of Cinéma Cent Ans De Jeunesse's exploratory approach (Chambers, 2020: 141): both projects - albeit in different ways - actively resist any degree of sedimentation or ossification, and are instead restlessly in pursuit of further degrees of progress. Alongside this exploratory impetus, however, Cinema en curs sensibly incorporates a counter-impulse of consolidation. Unlike Cinéma Cent Ans De Jeunesse, whose continually evolving, never-repeating curriculum is constantly in pursuit of uncharted territory (Chambers, 2020: 157), Cinema en curs's innovation is tempered to continually refining and improving a programme that is repeated annually, thus seeking to establish a pedagogy possessing both depth and longevity, in organic, dialogical conversation with the project's many participants. When a new arm or leg grows on the project, it is frequently in response to a need voiced by one of the project's participants, such as the inauguration of an international sister 
programme in 2014 - Moving Cinema (whose 2017 Transmitting Cinema conference is explored in the pages of the Film Education Journal by Aidelman and Colell, 2018) - in response to a question that arose from the project's young participants as to how they might continue to engage with film education once they were too old to participate in Cinema en curs.

Cinema en curs was established in 2005, with nine participating teachers and eighty students in five schools in various cities and towns across Catalonia. A subsequent timeline of key developments would include the first open call for Catalan schools to participate in 2007; the establishment of a new, autonomous sister programme dedicated to photography (Fotografia en curs) in 2012; and the first delivery of the project outside Catalonia, first in Madrid, Galicia and Argentina (2013), and subsequently in Chile (2014), Germany (2016; through Filmen Macht Schule), the Basque Country (2017; through Zinema (h)abian) and Mexico (2020). Further significant dates within the project's chronology include the foundation of the international Shots of the World day in 2019, in which Cinema en curs began to reach out to an even broader array of international collaborators, as discussed below, and the commencement of workshops for young unaccompanied migrants under the care of the Spanish administration in 2020. In the 2020/1 school year, Cinema en curs is working with 2,800 students, and 220 teachers across 44 schools in several regions of Spain (including Catalonia, Galicia, Madrid, Basque Country), Germany and Chile. In the 16 years in between, Aidelman and Colell estimate that more than twenty-two thousand students and four hundred and fifty teachers have participated in Cinema en curs, in more than five hundred workshops across more than one hundred schools.

Cinema en curs establishes an annually repeated, year-round curriculum in both primary and secondary schools, for students aged between 4 and 18. While this annual programme has evolved considerably since Cinema en curs's inception (and continues to evolve year-on-year in conversation with its participants), the general expectation is that the structure and approach of the project in any given year will be the same or similar to the previous year. The project takes place in state schools, during the school day. As explored below, A Bao A Qu sees the location of the project within the curricular space of the school day as crucial, as Aidelman describes: 'the workshops always happen in school time. The aim is to change school in this way, and also to have students be involved, but not as an extra-curricular activity. It's part of the learning and the possibilities that schools offer them.'

During the course of a year, participants move through a series of exercises designed to refocus their gaze and 'way of seeing' (Aidelman and Collel, 2014: 25), not only upon the expressive parameters of cinema, but also upon the world around them, culminating in the making of short films, which are then shared across the project. These practical exercises are frequently defined by a sense of rules or creative parameters that participants must work within, which 'aim at channelling and stimulating [creative activity, paying attention to very concrete cinematic aspects' (Aidelman and Collel, 2012: 126). In this respect, exercises are guided by a body of short film clips (ranging from 2 to 10 minutes in duration) selected in order to focus attention on certain parameters within cinema. A further key tenet of the project is the frequent presence of a film-maker in the classroom to collaborate on the project's delivery with the class teachers. While there are now routes through the project that do not require the presence of a filmmaker, the organisers continue to emphasise the importance of the presence of professional practitioners where possible, following Bergala's (2016: 38) theory of the film-maker as a 'passeur' who models a certain approach to, and perspective upon, cinema for younger participants. Over eighty professional film-makers have participated in the project thus far, including those with increasingly international reputations, such as Cannes prize-winner Carla Simón, Jonás Trueba, Celia Rico, Xacio Baño, Meritxell Colell and Jordi Morató.

In many of these respects, Cinema en curs can again be seen to be indebted to the precedent of Cinéma Cent Ans De Jeunesse, a sense of commonality that Aidelman and Colell (2012: 124) themselves have explicitly identified:

... above all, we share the same guidelines: 1 ) the presence in the class of one person from the world of cinema who works together with one or more instructors during the entire course; 2 ) linking practice with the screening of clips from all periods of cinema history; 3 ) the 
structuring of content around a main cinematographic issue (light, point of view, colour) [an aspect of the programme that has since been discontinued] and the existence of a shared program for all workshops; 4) the diversity of the participants (given by age, students from 8 to 18 , and geographical and socio-cultural context and only in public/state schools).

Nonetheless, while it maintains its ties with CCAJ as described above (Aidelman and Colell continue to participate actively on CCAJ's steering group, and a small number of participants in Catalonia follow the annual CCAJ curriculum verbatim), Cinema en curs has evolved a holistic approach to film education, with particular emphasis on engagements with place, community and environment, which are very much its own, and cut deep to the relationship between cinema and lived experience. As Aidelman and Colell (2014: 25) have written, Cinema en curs seeks to help young people discover 'an unknown cinema, which many believe to be far away from their interests but which can precisely be the nearest to them'.

There have been several English-language articles published to date exploring the work of Cinema en curs, most of them written by Aidelman and Colell themselves, exploring aspects of the project's underlying philosophy and justification. 'The pedagogical powers of cinematographic creation' details Cinema en curs's origins in close proximity with Cinéma Cent Ans De Jeunesse (Aidelman and Collel, 2012: 124), while detailing A Bao A Qu's prioritisation of open-ended 'experiences of creation' as processes of exploration and discovery. Aidelman and Colell (2012) here contrast such experiences with forms of learning premised upon more closed forms of signification, and information that can be easily memorised and repeated. As Aidelman and Colell (2012: 120) write:

... instead of conceiving artistic subjects as 'content' (by definition a limited, closed subject and thus, controllable and measurable), we approach artistic subjects as an experience, something that overwhelms us, astonishes us, moves us, touches us, shakes us. Art becomes a place for adventure.

Such notions relate directly to Cinema en curs's conception of cinema as a carrier not only for lived experience, but also for our relations to others:

Artistic creation returns us to our condition as subjects. It not only allows us to see things that went unnoticed, but it makes us aware of our own (and unique) sensitivity ... Besides letting us express and even discover our own experiences, art also brings us closer to the experiences of others and allows us to take part in, share and somehow understand them. (Aidelman and Colell, 2012: 120)

Published in Toma Uno in 2012, 'Cinema en curs: Transmission of film as creation and creation as experience' (published in a new English translation in the Film Education Journal (Aidelman Feldman and Colell Aparicio, 2021)) retreads similar ground, elaborating upon Cinema en curs's notion of experiential approaches to creation, while providing more detailed accounts of two of the project's key exercises, the since-discontinued Lumière Minutes, and the approach to the students' final films. The subsequent 'In praise of love: Cinema en curs' (Aidelman and Colell, 2014) situates the methodology and rationale of Cinema en curs within a broad cultural framework, drawing upon the work of Alain Bergala, Stefan Zweig, Vladimir Nabokov and Jean Renoir, among others. Aidelman and Colell (2014) here emphasise the importance of parallel and ultimately interlocking experiences of watching and making cinema. Returning to a recurrent preoccupation regarding the need for exploratory and experiential approaches to creativity within learning environments, Aidelman and Colell (2014: 26) contrast Cinema en curs's pedagogical focus upon open-ended experiences of creation with (perhaps provocatively for readers within British education) significant scepticism as to the value of approaches centred upon 'literacy':

To discover and comprehend art, and cinema in our case, is not related with the simple acquisition of technical terms, which usually is the starting point (and ending point) of most 'lessons on cinema'. An example of this kind of teaching ... is the description of the different 
shot scales; ... 'Equipped' with these terms, students 'analyze' film sequences and 'identify' these notions while they 'interpret their meaning'. In this logic, if the 'correct' words have identified the correct aspects of the sequence, the student shows his knowledge on the matter. But what has he actually seen? What has been learned? To identify something means to reduce it to an established term, to close it in a limited meaning, to impose what we already know over what we have seen. Therefore, in Cinema en curs we avoid the idea of 'literacy'. Amongst everyone who is literate, who is actually able to enjoy the words of a poem or the sentences of a character's description? Or, furthermore, does an alphabet for film, for paintings or poetry even exist?

Finally, a rare article on Cinema en curs not written by Aidelman and Colell, Felipe Correa's (2020) 'Immaterial cultural heritage and a sense of place in film-based art education', provides a decentralised case study outside Catalonia of the project at work in Chile, focusing in particular upon some of the more holistic aspects of Cinema en curs's methodology in helping young people engage with a sense of place (as will be discussed in greater detail below) and aspects of cultural heritage within local communities.

Given that most of these existing studies of Cinema en curs have tended to focus upon overviews of methodology and rationale written from relatively internal perspectives within the project, this essay seeks from a more external perspective to adopt a more grounded approach, balancing continued consideration of the project's more philosophical concerns, alongside that of the more worldly, logistical factors mediating its delivery. Alejandro Bachmann and Manuel Zahn (2018) have written of the imperative to consider the media-ecologies of film education: the contingent, worldly contexts in which the worthy ideals of film education projects are simultaneously constrained and afforded by material and institutional factors. Similarly, it would seem important, alongside previous discussions of Cinema en curs, to situate the project's highly compelling ideology within a frame of consideration alive to the nuances and particularities of practice on the ground.

In what follows, this article organises a series of conversations with Aidelman and Colell - conducted over Zoom during the first few months of 2021 - within two, interlocking perspectives upon Cinema en curs: first, following Bachmann and Zahn (2018), a media-ecological perspective considering the complex web of logistical factors - in terms of time management, recruitment of participants, and interactions with various institutions - that underscore the project's delivery; and, second, a methodological perspective looking at the ways in which the particular pedagogical approaches of Cinema en curs seek to achieve the lofty ambitions of which Aidelman and Colell have previously written.

\section{Media-ecological perspectives}

Considering the broader ecological contexts in which the project takes place, one of the most interesting questions for an international perspective upon Cinema en curs is how such an ambitious creative pedagogy is reconciled with the restrictions of established educational institutions and existing school curricula. This will no doubt be an ongoing dilemma with which many film education practitioners worldwide will be familiar, struggling against extant conservative notions of film's 'out-of-placed-ness' (and resulting otherness) in comparison with more traditionally condoned forms of culture, such as literature, music and dance. As discussed below, while Cinema en curs seems to have become adept at the awkward negotiation of reconciling film with the existing priorities of broader school curricula, the project simultaneously follows Alain Bergala's ciné-pedagogical approach in embracing the subsequent otherness that film possesses in school settings, as a potential source of pedagogical renewal and transformation. As Bergala (2016: 21) has written:

Art, in order to remain art, must remain a catalyst for anarchy, scandal, disorder. Art is by definition a sower of trouble within the institution. It cannot be understood by students without 
the experience of 'doing' and without contact with the artist, the craftsperson, like a 'foreign body' in the classroom, like a pleasantly disruptive element in the school's value system, its code of conduct, and its relational norms. Art must be neither the exclusive property nor the private domain of a specialist teacher. It must be an experience of a different nature, in the elementary classroom, than the one offered by a specialized course, as much for the students as for the teachers.

In certain respects, Cinema en curs embraces this otherness of cinema within curricular settings, resisting what Bergala (2016: 21) (recalling Adorno) has described as the institution's 'tendency to standardize, to amortize, indeed to absorb that element of risk represented by an encounter with any form of otherness, in order to reassure itself, and to reassure its agents'. Here, Cinema en curs looks beyond the specifics of film education towards more holistic, transformative outcomes, for, as Colell describes:

It's not about working with cinema in one group and transmitting cinema to them. There is also a pedagogical desire to change the methodology of the school. That's the ambition, and how our perspective has changed. When we started, it seemed quite a strange idea within a Spanish education context - having a film-maker in the school. Everyone thought it was a foolish idea. Then the main thing for us is to be able to change the process and the dynamics in the schools now.

Sometimes these changes are material, and very literally change the shape of the classroom in which Cinema en curs workshops take place:

We usually change the organisation of the classroom space itself. The tables and chairs are usually always in individual rows, and we change that - we move them around into ' $U$ ' shapes, or put small groups of students around tables scattered around the room, or create one big table for everyone to sit around. We change the space a lot, and we see the schools then using these changes outside of Cinema en curs.

Elsewhere, changes are made within the sense of ritual through which certain activities are approached. For example, the moment in which students use a camera to film something for the first time is explicitly emphasised and celebrated as a special occasion:

When the film shoot is finished, we will celebrate this first experience with applause, and later we will comment on what we appreciated during the shoot, whether something special happened, what surprised us ... This 'first time' is particularly important, as in a certain way it lays the foundation and shapes further practice of the students when they film alone in an independent manner.

Returning to broader overviews of the institutional contexts in which Cinema en curs takes place, Spanish education is constituted of a roughly equal split between public and private education, with Cinema en curs working only with the former. Within the Spanish school system, children attend primary school until the age of 12 , followed by mandatory secondary school until the age of 16 , and two subsequent optional years of college. When Cinema en curs first began in 2005, the project initially worked only with students aged between 10 and 18. In one of many instances in which the project changed shape in response to conversation with its users and participants, however, Aidelman and Colell were then approached by primary school teachers asking if their students too could participate in Cinema en curs, leading to the subsequent development of activities for younger students (aged between 4 and 9). As Aidelman describes: 'here, the principles are the same, but all the creative practice is done via photography. They don't start shooting moving images until later.' While Cinema en curs provides workshops throughout all four years of secondary school, they have deliberately chosen not to work with students in their final (optional) year of college, due to the level of curricular demand upon students. As Aidelman describes: 
We don't run workshops in the final year of secondary school, because it is so complicated within the students' timetables. They have so many exams and are all focused on university entrance exams. We would love to work with this age group, of course, but the system is very challenging and the students are stressed. We do continue to work with students in their first year of college, however, which is great, although here there are already tensions trying to work within their system, which is very rigid and the teachers are stressed. When Cinema en curs first began, we didn't work with this year group because our main objective has been to engage with young people who don't have the opportunity to discover this kind of cinema, and may not go to university. But then we started working with groups of 16 year olds, because it's so rich for people who want to discover art or cinema and to connect them to it in this very deep way. It also helps us to think of new approaches for Cinema en curs, not only with teachers, but also with the students.

While Cinema en curs continues to emphasise the importance of film-makers working in the classrooms as part of the workshops, in actuality - given the resource implications - only a very limited number of schools are able to work with a film-maker, and thus over the years, the project has evolved other routes in order to be able to open up access for a greater number of teachers and young people to participate:

We started a second circle of teachers, after the first circle of teachers who are working directly with the film-maker. Having worked with the project before, these teachers already have the methodology, the activities, and we (the organisation team) work with and support them in a very close way. But then, over the years, we started with new schools, and proposed this other kind of course for teachers who hadn't yet worked with film-makers. The principles and aims are the same, but the activities are different. For example, we don't do such detailed filmmaking activities with the teachers who haven't yet worked with film-makers - we do pieces of editing, creation of shots, sound, everything, but with using a simplified approach. It's a shorter process, not as long as the projects with film-makers. We specifically give them more simple activities, which are easier from an organisational and time-management perspective. The aims, however, are the same: discovering cinema, the environment, having an important experience. But the activities are different. These other workshops allow us to work with teachers that might not have the capacity to spend so much time on the project, or the possibility of a film-maker, they don't need to commit as much.

More recently, Cinema en curs has shifted its overall emphasis in order to work with a smaller number of schools, but in a more intensive manner in each one. Here, again, the emphasis seems to be on allowing the activities of Cinema en curs to grow in cumulative, organic ways that allow the warmth of conviviality generated by the project to spread outwards through a school, and sometimes even into the surrounding neighbourhood and community. Aidelman describes how:

An important change or development within Cinema en curs since we began is that the number of schools is bigger, but not that much bigger. Six years ago, we changed our focus and perspective to building a school project and to give resources to the entire school, not only those involved in the workshop. What has now changed in our approach is that in these schools, Cinema en curs is not only a workshop with a group, but is now a project that is able to transform the approach of the whole school.

Colell continues that:

It's not about the number of schools, but more about the number of people involved in schools. That's why we work with the same school for a long period of time. You can start with one group of teachers and then, year after year, you work with more. And then it becomes the whole school. And then it becomes the neighbourhood. And then the whole village. It's an important change in our perspective. 
Cinema en curs's approach to recruitment seems also to prioritise this sense of cumulative, convivial warmth, seeking to build outwards from spaces in which the project has found resonance, towards a broad, securely rooted sense of community between film-makers, teachers and project organisers. Indeed, it is frequently Cinema en curs's participating teachers themselves who now suggest potential new teachers to approach. Aidelman describes how:

We were lucky, in that in the first year of the project we worked with wonderful teachers. We are still working with all of them. Some of them are retired, but they are still connected to the project, 16 years later. In our initial phase of the project, we relied on external means to locate suitable teachers. A public servant in the educational department in Catalunya contacted some teachers who they thought would be suitable. Whilst we have since come to the conclusion that this is not the best method of recruitment, we were lucky that the teachers who initially became involved with Cinema en curs in this way were already connected to cinema and the cinema experience. When we explained our initial ideas to them, they were fascinated, and really started thinking from that first day onwards about all the opportunities this would offer their students. They understood the pedagogical potential as well as or even better than us from that first moment. They came from different contexts because we had asked for that - teachers from rural places, from cities, from very difficult, poor contexts. Over the years, when it was our tenth edition, we really realised the opportunity we had with them and how important it was. If we hadn't started with such a good team, the project might not have continued. Everything comes from them: they broadened the scope of the project with schools over time, contributed ideas and confidence.

Interestingly, Aidelman and Colell have found that teachers who already have relatively fixed notions of cinema and what it takes to make a 'good film' are not always the most suitable participants for the project. Colell describes how:

We meet with possible new participants, and have learned over time what we need to know about the schools to know if they are suitable for the project. For us, the most important thing is that the teachers want to participate in this project for the sake of their pupils. It seems obvious, but it's not. Cinema en curs is not a project to make beautiful films or learn technical skills. It's a project to offer something important to your students on a personal level, a community level. To make their life and learning better. When a teacher is really obsessed with technique ... usually it's teachers who already do a lot of things related to cinema, they want to improve their cinema skills and become more professional. These teachers we absolutely have to discard. They're already doing things, which is great. But they don't have the same expectations that we have of the project.

One of the central tenets of Cinema en curs's philosophy of film education as an 'experience of creation' is the importance of developing a quality of attention in students, both towards cinema (in their work as film-makers and audience members) and the world around them. Such an approach inevitably takes time, and the project therefore asks for a relatively significant time commitment, as Aidelman details:

It's difficult to say precisely, but Cinema en curs tends to take between three and six hours per week, including one session lasting at least two consecutive hours. The ideal situation is to have four hours in a week made up of two consecutive blocks of time. However, when it comes to shooting and editing the final films, we work additional hours that are not included in this. At this point in the year, shooting can take all morning, or the whole day and even the night. Schools are expected to be able to organise specific special days for shooting and also for editing the film. During the edits, the film-maker is there all day working with three to five students at a time, and then the whole group to watch together. There are some workshops for schools which are far from Barcelona, and you have to travel to them. So for them, it's 
mandatory to have the whole day free for when the film-maker is coming. If the trip takes two hours to get there, then school is booked to have an all-day session. They work in little groups, and we change activities and the group sizes. It means there are fewer sessions with film-makers, but the sessions are longer.

Another key factor in terms of how time is organised in Cinema en curs - again in the instances when filmmakers are working in the classroom - is the balance of time between moments in which the film-maker is present, and those in which they are not. As Colell notes, while:

... participation in Cinema en curs tends to take more or less 120 or 140 hours per year for each class, it is important to note that the film-maker isn't there all the time. They only go to school once per week. It might be two hours with a film-maker, and then two hours with the teacher.

Correspondingly, Cinema en curs take care to emphasise that the relationship between the film-maker and teachers needs to be collaborative, as Aidelman describes:

The film-makers have to be socially focused and sensitive enough to work with children. And they have to be able to work together with the teachers. For us, it's very important that the teacher and film-maker work in tandem. It can't be a film-maker who comes in and thinks they are the star of the show, and the teacher steps aside for them. We want them to work together. We need a person who has both cinematographic skill and personal and social sensitivity - which is quite rare.

The size of groups is another important factor in Cinema en curs's attempts to open up spaces in which students can develop a focused quality of attention upon cinema and the outside world. When thinking about the size of groups, Cinema en curs has learned to take into account both the number of the whole class, and how that group is then able to subdivide into smaller groups. There is therefore, as Aidelman describes, 'a certain equation between the number of students, the number of teachers involved and the number of hours available'. Colell elaborates that:

With two teachers, you can divide the group. The law says that students can't be alone with a film-maker. A teacher must be present. However, if you work with more than one teacher, you can work in much smaller groups and this allows us to change the dynamics. In this respect, it is better to have thirty students with two teachers than twenty students with one teacher.

Aidelman continues that:

In our open call to schools, we ask that there will be two teachers with a group. The most common group size is between 20 and 25 students with two teachers. If there are 30 younger students with only one teacher, who have only three hours to participate, and do not much have much autonomy in terms of what they are allowed to do on their own, it can be very difficult to work in this way. In comparison, in the later years of secondary school, when students are 16 or 17 , there are always 30 or 35 in a class. Whilst this is a lot of people, they have four hours to participate, are very autonomous and have the capacity to work either together or alone. Whilst we may only have four hours a week, students at this level tend to spend a lot of extra hours working alone. At this level, we frequently find that their teachers and the participating film-makers will work with them outside these four hours. They drive or email them, or go on shoots with them. So they can be a big group. But if it's a group of newcomers, there are usually only 15 students, maximum 20 because you need to work closely and take time with everything. 
The chance to have two teachers working within any given iteration of Cinema en curs is productive not simply for the affordances it creates for group work, but also for the benefits it creates for teachers themselves to work collaboratively together. Aidelman describes how:

When we started, it was very, very uncommon to have two teachers in the classroom. Now, step by step, it's becoming more common, and is something that is appreciated by the teachers themselves. They learn together, work together, and in doing so develop more pedagogical skills and methods - not only about Cinema en curs, but for their professional life and interactions with students. It's true some teachers aren't used to working with other adults in the classroom, and it can be a bit uncomfortable for them. For the students, it's also novel for them to see adults working together - the teacher and film-maker talking and deciding, and complementing each other.

Over the 16 years working within the project, Cinema en Curs has become adept at finding ways to reconcile project activities within the pre-existing structure of the curriculum. Aidelman and Colell take care to emphasise, however, that this is a careful balance, where too much compromise can be damaging:

The teachers we work with are trying to think and work in new ways. If they are very worried about the curriculum, then we can't work together. If they are focused on the traditional curriculum and learning in this way, it's just impossible. We seek teachers who are progressive and trying to change things. We also want to work with schools that are keen to experiment maybe because they have a challenging environment. They get involved with the project because they want to change the school.

In primary school, of course, they understand better that film is transversal and connects to language, to social knowledge, all the competencies. In primary, they understand learning in a more flexible and versatile way. Then, in secondary school, it depends a lot on each schoolwe work a lot in artistic strands and subject areas, but also nowadays more schools have 'project time'. This is a strand in the timetable for projects, which is great because they know they're working transversal across several subject areas. They have four or six hours' project time per week.

Colell expands that:

It can be a scientific project or a social project or an artistic project. Cinema en curs covers all the requisite dimensions - technical, historical, social, artistic. We also have some workshops that are linked to language areas. We work a lot on self-expression, writing and oral expression. So it depends on the school, and when we publish the open call for schools to participate, we explain that it's important that each school thinks about how to articulate the project in this learning context. It's not the same for all the schools, and that's an important point. The school knows how to do it best within their own context. The most basic area in which Cinema en curs intersects with the priorities of the curriculum is languages. We work a lot with blogs, and think about how we express ourselves and how we discuss things. Not just with written work, but also how to approach elderly people if you want to talk to them, an interview. We are very reflective and attentive about all these language processes. But always in this experience-based way of learning - because it's not a text that the students have to read about. It's about asking: Who is our main character in the film? How would you describe this character?

Following the initiative of some of its participating teachers, Cinema en curs is even starting to explore ways in which aspects of the project can be graded as part of school assessments, an occurrence relatively rare in film education projects instigated by external organisations. Colell describes how: 
We have a group of teachers that think a lot about the evaluation process of Cinema en curs because it's a project which is part of the school timetable. It's linked to their subjects. You have to evaluate the students. For us it was a very difficult question: How do we evaluate this kind of process? We have a group of teachers who think a lot about this, and they created a list of evaluation criteria. There's this thing in these sorts of projects where you have to evaluate the 'attitude' and the 'participation'. We think it's not only the attitude and the participation, but also what they are learning in terms of creativity, in terms of technology, in terms of language, in terms of group participation and vocabulary. We have a very long, detailed list to use. It's interesting to have it, and the teachers say they have real evidence of the learning and knowledge that students achieve from this project.

Aidelman argues that there is growing evidence that Cinema en curs's holistic approach has significant benefits for students' wider academic development in areas beyond film education:

We see that groups who participate in Cinema in curs tend to have better academic results in other subject areas. One could say that they [the teachers] are subversive and against the institutions and classical system, but really they are concerned about the learning of their students. They really are thinking about how to make the best learning possible, and they realise our project makes the learning better. One example of this from Cinema en curs can be seen in the level of expression. You can see a text written by a Cinema en curs student on the first day - a short text showing how they express themselves. And then, if you read a text by the same student at the end of the project, you see a lot of changes. Not only in how they express themselves in the text, but also how they are thinking and the level of oral expression. We have noticed that sometimes when you have a group of students, some of them interrupt politely in a specific way and say 'First of all, thank you for your contribution ...'. You realise, 'Ah, they must be a Cinema en curs student!' Their way of communicating is more developed.

Having considered some of the more ecological factors - organisational and institutional - pertaining to the contexts in which Cinema en curs is delivered, the following section will consider the project's methodology, and how Cinema en curs's particular approach to pedagogy seeks to yield benefits for its young learners, both in terms of film education and beyond.

\section{Methodological perspectives}

A year of Cinema en curs currently begins with the Shots of the World exercise (discussed in detail below), which is filmed largely on equipment students themselves have access to, such as smartphones and simple cameras. Following this, students are introduced to a professional digital camera, and they work in groups upon an exercise called Light and Faces (Cinema en curs, 2015), designed to help focus participants' attention upon specific cinematic parameters, and to begin approaching the camera as an expressive, as well as a technical instrument. The process of developing the students' final films starts as early as December, when script work begins. Over the next couple of months, while scripts are developed for final films, students simultaneously work on a series of exercises, largely shot autonomously with their own equipment. The intention is that students link the script they are developing with these lighter forms of practice, conducted with their own equipment. Towards the end of February in any given year, activity starts to focus upon shooting short segments, now with the professional camera, with each in miniature working through the same process of conceiving, shooting and editing that will ultimately be adopted to make the final film. Towards the end of April, three or four days are spent shooting each of the films, followed by several weeks of editing. Finally, all the films are presented at celebratory screening events at which the students come together to present and reflect upon their own work, while responding to that of others. 
Returning to the emphasis that Aidelman and Colell have placed upon experiential approaches to film education, much of Cinema en curs's structure exists in order to open up moments in which the project's young participants are able to dedicate focused moments of attention, not just upon cinema, but also upon the world around them. Aidelman describes how:

For us, attention is the central methodology or crucial approach to everything that we do. Paying a lot of attention. Cinema is a way of looking and relating to the world and to others. Our essential approach is that cinema is a way of being in the world. It's an opportunity to look at the world in a new way, and find other ways to relate to places and people. When you make cinema, you spend time and have to relate to the places and people that you are filming. For us, one of the most important results of the project is that children start looking at their environment with a different gaze. Taking time to be in the place, taking time to be with people. Then, during the practices and all the activities, we have an objective of relating to the place and the world around you. It's both in the conception of cinema and in the development of the activities. We work a lot using a documentary approach, being inspired by the reality around us.

Here, Cinema en curs's highly particularised conception of cinema can be seen to be rooted not just in documentary film-making and notions of realism ('We work a lot using a documentary approach, being inspired by the reality around us,' Aidelman says), but also in the direct, subjective experience of each of its participants. The focus on place and community that Felipe Correa (2020) has elsewhere explored in the project's delivery in Chile can be understood within a more holistic philosophy of cinema as rooted in sensory, lived experiences of the local and the nearby: of dialect, autochthony and ontology. Interestingly, as explored elsewhere in film education discourses (Chambers, forthcoming; Shand, 2021), this is directly in contrast to the arguably alienated approach that many young people adopt to cinema as something that takes place elsewhere - an exoticist, transcendent medium, far removed from the seemingly mundane, rooted experiences of their daily lives. Similar to the seminal opening of Bill Douglas's My Ain Folk (1973), the transportive medium of cinema is a technicolour experience of escape, whereas the bleak drudgery of daily life outside takes place in black and white. Rather, Cinema en curs positions cinema not elsewhere but here - as arising from the everyday lives, experiences, places and communities of its participants. As Colell says, 'a thing that's really revolutionary for the pupils - and this is what we are interested in ourselves - is discovering that cinema is what happens in our lives'. In a certain respect, Cinema en curs's invitation to see again, and to re-evaluate the places and people we may have taken for granted, can here be seen to have notable resonance with mindfulness philosophies encouraging the active paying of attention and re-engaging with the senses, as expressed in R.S. Thomas's poem 'The bright field' (quoted in Williams et al., 2007: 137): 'I have seen the sun break through / to illuminate a small field / for a while, and gone my way / and forgotten it'.

As I have explored elsewhere (Chambers, forthcoming), an approach to cinema premised upon this sort of re-engagement with dialect, locality and lived experience often involves complex unlearnings of assumptions of what cinema is, and what cinema can be about. In Cinema en curs, this effort is ingrained into the project's chronology of activities, starting with exercises designed to help reorient the gaze, not merely to acclimatise to the expressive cinematic parameters such as light and colour, but also to reawaken curiosity more generally to the sensory properties of the world around us. While previously Cinema en curs started with the Lumière Minutes exercise (Aidelman Feldman and Colell Aparicio, 2021: 64) inherited from CCAJ, in which participants would each make a one-minute documentary from a static camera perspective, following the same constraints and affordances that the Lumière brothers experienced at the dawn of cinema, the project now starts with an exercise entitled Shots of the World, introduced in 2015. Aidelman describes how:

We used to start with the Lumière Minute, but we changed this because, although the Lumière Minute is very strong in terms of cinematographic experience, and we still work with 
it, it takes a lot of time, and is a complex process. We felt the first approach, rather than being heavy, has to be light-hearted and direct, to make young people start making films and watch their films via another gaze.

Whilst the Lumière Minutes required students to have to look for a very specific kind of thing [to film], Shots of the World is the opposite. You can look at and find whatever you like. The idea is, you start looking around you, with some precise indications like the light, the sky, the view ... after watching the clips, the importance of the frame. It's a strong cinematographic experience, looking from the window, looking from a hill, looking from the streets, but within very specific cinematographic parameters. We start shooting in this way on the second day of the workshop. The students shoot in little groups with the film-maker and the teacher. It's their first experience of cinema, which is very important. We start with photo cameras in school. Then young people start shooting on their mobiles, or their parents' mobiles, if they're very young. So everyone has the tools they need to make cinema from the very first day. They have the tools and the framework within this activity to have a film-maker's view on the world, and start looking at the environment in a new way. It's the starting point, and all workshops have been developed from this experience.

Aidelman and Colell see Shots of the World as being a first step in unlearning assumptions as to what cinema is or could be, and are gently firm in their insistence that all Cinema en curs participants adopt this approach:

Our starting point of the Shots of the World is very decisive in this sense: we start with another kind of cinema. We are very clear when we are devising and explaining the framework to teachers and students alike - that we will work with films that are about ourselves and our environment. And if students want to make other kinds of films, then that's great, they can do it in their leisure time. You can make many films in your life. Just because we propose this kind of film doesn't mean you can't make other kinds. But we say that we are now taking the opportunity of being together in the school, doing this specific project. We are very clear. We don't ask them what kind of film they'd like to make. We say: 'We are making a film in this framework.' Then they decide what it will be about, and they make it. But the framework is clear from the start - not as a limitation, but as an opportunity this year for them to do something great.

Colell emphasises that this approach to film - rather than appealing to pre-existing genre categories opens up the possibility for the unique experiences and composition of the group to express itself:

If students ask 'Why this kind of cinema?', we answer: 'Because we know it will be very important for us as a group. It will be a really important experience in our lives. For this reason we're doing it.' Here, it is important to emphasise that the film we are making is a film that only this group can make. It's our film. It's special and specific because of us, the group who is here. A zombie film, a superhero film, doesn't depend on who we are. This film we are making is only possible because we are making it together.

Similarly to Cinéma Cent Ans De Jeunesse, Cinema en curs employs a curated series of short film clips to assist students in fostering new 'ways of seeing', and simultaneously unlearning and relearning aspects of their own gazes. One of the key influences upon the Shots of the World exercise in particular was the experimental Israeli film-maker David Perlov, whose six-part cinematic 'Diary' used documentary cinema to enable a new engagement with intimate personal experiences. As Perlov narrates in the opening of the film:

May 1973. I buy a camera. I want to start filming by myself and for myself. Professional cinema does no longer attract me. To look for something else. I want to approach the everyday. Above all in anonymity. It takes time to learn how to do it. 
Such clips are used, not only to initiate students into new ways of seeing, but also to help them focus upon specific cinematic parameters, such as light, as Aidelman describes:

We discover the value of light by watching the clips and talking about it - What is light? What time of day is it? When do you think this was filmed - afternoon, morning? Perlov is one of the first clips we work with: there is a special afternoon light that changes a bit after three shots. We also use excerpts from Victor Erice's film Dream of Light: The quince tree sun, where there's a night sequence in Madrid showing all the little lights in the buildings. Students start paying attention to the clips, and then we encourage them to shoot at particular times in their own work: 'It would be wonderful if someone can shoot in the afternoon in this special light at 5 or 6 p.m., or in the morning before coming to school.' We propose this to them, and then there's an important moment in each workshop - the first night shoot, the blue hour, the magic hour. Each student's first shot in this special light is incredible for the group. Then all the others start wanting to shoot in this special light. They really appreciate it. When they start, they recognise its value, it's very direct. But you need to have one person who does it first, and then the others follow.

Returning to discussions of institutional ecology and the various affordances and limitations this creates, Cinema en curs's commitment to the particularities of place and light raises certain, inevitable logistical problems. Indeed, writing from Scotland, while practical film education projects often involve a certain relaxing in terms of school expectations (I have worked on projects myself where we have ended up filming in students' homes, or meeting parents in the playground before school starts to go and film on the beach together), it is difficult to imagine British teachers meeting students on the beach at 7 a.m. in order to film in a certain quality of light, a situation that it would seem is not infrequent in Cinema en curs. Aidelman and Colell describe how, while approaches to student film production are indeed more relaxed in comparison to the UK or Germany, these sorts of liberties are also becoming more difficult in Spain:

It is true that in Spain over the years, it has been becoming worse, in terms of legal tensions. In the first year, no one cared about everyone getting into cars together and going from one place to another. Since then, they have started to ask for parents' permission. Some teachers don't want to go out in cars. The question about image rights is also getting worse. It is also important to say, however, that we work with extraordinary teachers. It is not the case that all teachers in Spain would do this. It is not necessary to meet at seven in the morning before school. We do feel it is necessary, however, to be able to go outside and shoot outside during school hours. For us, it is a key condition to participate in the project. So it is important that students can go outside in a small group during school hours. And also to shoot in the afternoon, evening and night, because it's really moving and transforms you. It's a vital and relevant experience to shoot in the special hour. It's not mandatory to do these things outside of school time ... but it is mandatory to let them go outside. It is also important to say that these things are, of course, easier in the small towns and villages. Everything is calm and relaxed. In the cities, it depends. It can be easier in what are considered the more 'difficult' schools located in the outskirts, where young people are used to being outside in the streets. It's easier here than the schools in the city centre, where there is a lot of academic pressure on students and also the environment isn't as cinematographic for these activities. In the periphery, the limits of the cities, things tend to work better.

Counterbalancing Cinema en curs's emphasis on the more abstract parameters of place and light is an incisive approach to emotion, which is powerfully legible in students' final films. Aidelman describes the importance of participants:

connecting in a very deep way with the emotions of the character and their emotional world. It's not common at all in school to talk about emotions, to express emotion, to reflect on emotions. 
It doesn't happen. It might be used as a specific theme in some subjects, like 'bullying'. But in school, it's unusual to discuss real emotions and worries. How to react to them. In this sense, we do a lot of very important work, talking about emotions, and then putting it in the character and getting to know the character's emotions. It's script work, but not in a classic script way. We work in a pedagogical way, thinking about the character and his emotions. We watch films in the same way, for example Truffaut's The 400 Blows, or clips - we always pay attention to the emotions. The clips inspire us and we are very attentive to the film-maker's choices, discussing how it achieves its power and how it is expressing emotions. Cinema is an art of the emotions - not because of what a character says, but because of how it is shot. It's key. We say we will express emotions by shooting - and, of course, through sound and editing - but not by talking. How can we express it via cinema? We learn this through the clips.

Indeed, as is beginning to be explored elsewhere in the pages of the Film Education Journal, the question of what in Britain might be called emotional literacy (Chambers, forthcoming) (although Aidelman and Colell might object to the expression) would seem to be an area of film education worthy of significant further exploration, regarding the opportunities that film creates to explore complex personal issues arising in students' lives.

\section{Conclusion}

Knitting together these interlocking media-ecological and methodological perspectives upon Cinema en curs affords a newly dimensioned portrait of a highly sophisticated, and ambitious, film education project which - alongside the passionate idealistic justifications Aidelman and Colell (2012, 2014, 2018; Aidelman Feldman and Colell Aparicio, 2021) have presented in previous publications - is able to balance a complex, holistic and laudably idealistic approach to film education, with a sophisticated, pragmatic understanding of logistical considerations.

Based as it is around a series of interviews with key personnel involved with its delivery, the perspective on Cinema en curs presented in this article is largely in a celebratory register, considering the project's achievements to date. While further research is thus required in order to evaluate and quantify the project's activities within a more critical capacity, a certain sense of the project's relative achievement can be ascertained by viewing the resulting work produced within the project, much of which is available to watch on Cinema en curs's website (https://www. cinemaencurs.org/). Here, as would often seem to be the case with film education projects, the films produced by Cinema en curs frequently speak for themselves, the project producing an ongoing stream of student work remarkable for its aesthetic sophistication, emotional intelligence and depth of engagement with lived experience. One example among many, La Solitud (Loneliness) (https://www.cinemaencurs.org/en/film/la-solitud), is a powerful invocation of a troubled experience of adolescence, weaving together naturalistic performances, documentary footage of Barcelona interspersed with moments of drama, and a nod to the climactic sequence of Truffaut's The 400 Blows, with striking sensitivity and erudition. A striking affirmation, it would seem, for a pedagogy premised upon open-ended experiences of creation. When I first saw the film at the Cinémathèque Français as part of 2013 Cinéma Cent Ans De Jeunesse screenings, I went to express my admiration to Aidelman and Colell for the project's achievement. They thanked me politely for my words, but asked that I address these compliments instead to the students who had directed the film.

One final underlying complexity within Cinema en curs remains worthy of mention. Despite the powerful affirmations that Cinema en curs seeks for student subjectivity on a personal and individualistic level, Aidelman and Colell take care to emphasise throughout their discussion of the project that such powerful personal experiences of cinema - whether in the act of making or watching - are moments when the individual and the collective intersect: while the intimate, personal renderings of lived experience are important, so are the moments when these are shared, discussed, or - indeed - constructed as a group. As Colell remarks: 
The sharing is essential. We start shooting together in small groups. The first time, it is always done collectively. Then, they shoot individually. They have a real desire to share this moment with their peers and it's very important to build [the relationship between] this group by commenting on their shoots. It's important to talk about the shooting and it's an important moment for each of them to see their shoots on screen and hear other people talk about them. It's also a way to build the group. It's not an individual experience, even if they are shooting individually.

In 2020, Cinema en curs instigated an international Shots of the World day, in which - on 12 November each of the project's participants across Spain, as well as participants in Germany, Slovenia and Lithuania, filmed a 'shot of the world' which was then uploaded to YouTube. The day reportedly had the character of a festival: a celebrative, communal rite in which disparate and diverse young people across Europe first shot, and then shared, their perspectives upon the places in which they live. Fittingly, the idea for Shots of the World came from one of Cinema en curs's participating teachers. As with many of Cinema en curs's activities, here the personal - students rendering their own perspectives through cinema out of windows or on deserted beaches in the early hours of the morning during the COVID-19 lockdown - was again inextricably entangled with the collective and the communal - part of an ongoing, organic dialectic shaped by a growing number of participants both in and outside Catalonia. As Colell concludes, Shots of the World celebrates the collective act of cinema as a means of interconnection and conviviality: 'It's a wonderful way to share cinema and share life. This for us is one of the great possibilities of cinema - all the sharing you can do around cinema with people near and far.'

\section{Declarations and conflicts of interest}

\section{Research ethics statement}

The author conducted the research reported in this article in accordance with Edinburgh College of Art standards.

\section{Consent for publication statement}

The author declares that research participants' informed consent to publication of findings - including photos, videos and any personal or identifiable information - was secured prior to publication.

\section{Conflicts of interest statement}

The author is Editor-in-Chief for this journal. All efforts to sufficiently blind the author during peer review of this article have been made. The author declares no further conflicts with this article.

\section{Filmography}

The 400 Blows (FR 1959, François Truffaut)

Diary (IL 1983, David Perlov)

Dream of Light: The quince tree sun (ES 1992, Victor Erice)

My Ain Folk (GB 1973, Bill Douglas)

\section{References}

Aidelman, N. and Colell, L. (2012) 'The pedagogical powers of cinematographic creation'. In B. Henzler, W. Pauleit, C. Rüffert, K.-H. Schmid and A. Tews (eds), Learning from the cinema: international perspectives on film education. Berlin: Bertz + Fischer, 120-9. 
Aidelman, N. and Colell, L. (2014) 'In praise of love: Cinema en curs'. Cinema Comparative Cinema, 5 (2), 24-30. Accessed 7 August 2021. https://core.ac.uk/download/pdf/39150703.pdf.

Aidelman, N. and Colell, L. (2018) 'Transmitting cinema: Some proposals for our time'. Film Education Journal, 1 (2), 14762. https://doi.org/10.18546/FEJ.01.2.04.

Aidelman Feldman, N. and Colell Aparicio, L. (2021) 'Cinema en curs: Transmission of film as creation and creation as experience'. Film Education Journal, 4 (1), 58-70. https://doi.org/10.14324/FEJ.04.1.05.

Bachmann, A. and Zahn, M. (2018) 'Film education as a multiplicity of practices: A media-ecological perspective'. Film Education Journal, 1 (1), 78-89. https://doi.org/10.18546/FEJ.01.1.07.

Bergala, A. (2016) The Cinema Hypothesis: Teaching cinema in the classroom and beyond (FilmmuseumSynemaPublikationen 28). Trans. M. Whittle. Vienna: Austrian Film Museum.

Burn, A. (2018) 'Reflections on The Cinema Hypothesis: A response to Alain Bergala'. Film Education Journal, 1 (1), $51-63$. https://doi.org/10.18546/FEJ.01.1.05.

Chambers, J. (2018) 'Towards an open cinema: Revisiting Alain Bergala's The Cinema Hypothesis within a global field of film education'. Film Education Journal, 1 (1), 35-50. https://doi.org/10.18546/FEJ.01.1.04.

Chambers, J. (2020) 'Consolidating an experimental pedagogy: Exploring ecologies of film education within France's Cinéma Cent Ans De Jeunesse and Scotland's Understanding Cinema project(s) between 2013 and 2019'. Film Education Journal, 3 (2), 138-59. https://doi.org/10.14324/FEJ.03.2.03.

Chambers, J. (forthcoming) "“We know what it's actually like": Voice, dialect and self-efficacy in Scotland's Understanding Cinema project'. In K. Lury (ed.), The Child and Film. London: BFI and Bloomsbury.

Cinema en curs (2015) 'Llum i rostre: Interiors'. Accessed 7 August 2021. https://www.cinemaencurs.org/en/expressivecategory-film/light-and-face?page=1.

Correa, F. (2020) 'Immaterial cultural heritage and a sense of place in film-based art education: A case study of a documentary film project with secondary school children as part of Cine en curso Chile'. Film Education Journal, 3 (2), 123-37. https://doi.org/10.14324/FEJ.03.2.02.

Gibbs, A. (2018) 'Film education otherwise: A response to Bergala's dialectics of cinema and schooling'. Film Education Journal, 1 (1), 90-100. https://doi.org/10.18546/FEJ.01.1.08.

Reid, M. (2018) 'Film education in Europe: National cultures or European identity?' Film Education Journal, 1 (1), 5-15. https://doi.org/10.18546/FEJ.01.1.02.

Shand, R. (2021) 'Excitement lies elsewhere: Teenage film-makers and popular culture'. Film Education Journal, 4 (2), 195-211. https://doi.org/10.14324/FEJ.04.2.08.

Williams, M., Teasdale, J., Segal, Z. and Kabat-Zinn, J. (2007) The Mindful Way Through Depression. New York: The Guilford Press. 